$$
\begin{aligned}
& \text { E66-M-92067 } \\
& \text { conf-970501-13 }
\end{aligned}
$$

\title{
NUCLEAR FUELS FOR VERY HIGH TEMPERATURE APPLICATIONS
}

\author{
L. B. Lundberg and R. R. Hobbins \\ Idaho National Engineering Laboratory \\ EG\&G Idaho, Inc.
}

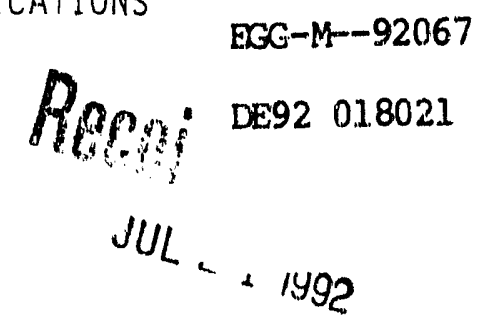

\begin{abstract}
The success of the development of nuclear therinal propulsion devices and thermionic space nuclear power generation systems depends on the successiul utilization of nuclear fuel materials at comperatures in the range 2000 to $3500 \mathrm{~K}$. Problems associated with the utilization of uraniurn bearing fuel materials at these very high temperatures while maintaining them in the solid state for the required operaling limes are addressed. The critical issues addressed include evaporation, melling, reactor neutron specirum, high temperature chemical sability, fabrication, lission induced swellirg, fission product release, high temperature creep, thermal shock resistance, and fuel density, both mass and fissile atom. Candidate fuel materials for this lemperature range are based on $\mathrm{UO}_{2}$ or uranium carbides. Evaporation suppression, such as a sealed cladding, is required for either fuel base. Nuclear performance dala needed for design are sparse for all candidate fuel forms in this temperature range, sipecially al the higher temperatures.
\end{abstract}

\section{DITRODUCTION}

The renewed interest in the development of space nuclear propulsion systems and high temperature thermionic-based space nuclear power systems brings forth a renewed interest in nuclear fuel forms that can be considered lor these very demariding applications. The nuclear fuel that will gencrite the heat in these advanced concepts is probably the most critical and challenging component of these systems.

New, advanced space nuclear thermal propulsion (NTP) devices are being designed to produce large amounts of high performance rocket thust using hydrogen heuled in the reditor core to ternperatures in excess of $3000 \mathrm{~K} .^{1}$ Fue. lcmperatures in these desigris will easily exceed $3200 \mathrm{~K}$. and the heat generation rates in these fuels will be very high (typicully $>20 \mathrm{GW} / \mathrm{m}^{3}$ ). Fuel burnup levels in these devices are usually anucipated to be considerably less than IT FIMA. A kcy feature of all solid fuel forms proposed for use in NTP reachors is their high surface-10-volume ratios. which is dictilted by the need to transfer the fission heall very rapidly to the propellant gas without overheating the fucl. High surlace lo voiume ratio and high heat tlux force 4.2 fuel structures or forms to be characteristically very thin and typified by geometries such as small spheres or thin plates. These extreme service demands and relatively fragile fuel structures will certanly lima the operating life of NTP reaciors to only a few minules or a lew hours. Typical maximum NTP reactor operating times are not expected exceed 10 hours. Fuel lorms based on uranium carbide are considered as prime candidales tor the advanced NTP sy'stems.

Advanced spasce nuclear power (SNP) systems that utitie thermionic devices for the generation of electrictly are being designed with fual element sultace comperatures as high as $2250 \mathrm{~K}$ and peak lue! temperatures as high as $2600 \mathrm{~K}$. The highest temperature thermionic SNP system concept, called the small ex-core heat pipe thermionic reactor (SEHPTR), involves the transfer of fission heal to the electrical generating devices by radiation acros's a vacuum gap. 2 Tungsten clad $\mathrm{UO}_{2}$ is being considered for use in SEHPTR and in a slighdy older concept callew the thermionic fuel elemen (TFE), which operates with luet cladding surlace icmperatures closer to $1300 \mathrm{~K}$.

The power dencitics of these readotors are lypically much lower than for NTP reactors (typically $<100 \mathrm{MW} / \mathrm{m}^{3}$ for SNP reactors), but the operating limes are much longer (up to 10 years). Fuel burnup levels in these devices are also ancicipated 10 be low, Iypically less than $5 \%$ FIMA.

Some of the thermionic-based space nuciear power systerns may also be used to generate satellite maneuvering thrust as well as electricity. A modest amount of rocket thrust might be produced by passing hydrogen through the sime reactor core that produces heat for the generation of elecuricity

Very high lemperature nuclear luels have been used in only id ices reactors over the years. The most notable of which are the lest reactors built and operated in the NTP developnent program generally relerred as Rover/NERVA. In one calse. hydrogen propellan gas was heated to slightly over 25()$(0) \mathrm{K}$ in an experimental NTP reacior using tuet that consisted of pyrolytic-carbon-coated $U C_{2}$ partacies imbedued in graphite siructures that were coalted with $\mathrm{ZrC}$ to minimize graphite altack by the hydrogen. ${ }^{4} 11 i_{2}$ important to realize that even though these luels performed reasonably well, they cunnol be considered as fully developed even for the cemperdure regume that was lested in the RoveriNER VA program. 
$\mathrm{UO}_{2}$-tungsten cernets were considered very seriously for use in several NTP systems designed to heat hydrogen to iempe:atures similar to those produced in Rover/NERVA sy'stems. ${ }^{5.7}$ However, no reactors were ever built and operated that used this cermet fuel form.

This paper will discuss the fuel design issues for reactors that operate in the temperature range 2000 to $3500 \mathrm{~K}$. We will also briefly indicate the state of the database for candidate fuels in this temperature range. However, we will limit our discussions 10 uranium bearing fuel forms that are based on uranium dioxide or the uranium carbides, and we will only consider those material-related design issues that we feel are representative of those that bear on system feasibility. Wc will not consider the uranium nitricus because of their lack of chemical stability in this temperalure range.

\section{HIGH TEMPERATURE NUCLEAR FUEL DESIGN ISSUES}

Many of the design issues for high temperature nuclear fuels are unique and significantly different from those that are used in the design of reactors w ith fuel operating lemperalures below $2000 \mathrm{~K}$. The high-temperature nuclear fuel design issues are listed below in a rough order of decreasing importance.

\author{
Material evaporation... \\ Meling temperatures... \\ Uranium densily... \\ Reactor neutron spectrum... \\ High temperature chemical stability... \\ Fabrication... \\ Fission product release... \\ Fuel swelling... \\ High-temperature creep... \\ Thermal shock resistance... \\ Mass densily...
}

Fuel ivaporation rates become very high at temperatures above $2060 \mathrm{~K}$, and fuel evaporation is probably the most important limiting factor in the application of uranium-bearing nuclear fuels at high temperatures. This limitation is mostly governed by the high volatility of uranium which can be only' partly suppressed by chemical combination 10 form more stable compounds such as $\mathrm{UC}_{2}$ or $\mathrm{UO}_{2}$.

Loss of material by high temperature evanoration is a time-temperature dependent process, so that probably the most signiticant set of design parameters is the evaporation loss rate as a function of temperature. A plot of evaporation loss rates of several candidate high-temperature luels and tungsten is presented in Fig. 1 to indicate the magnitide of the evaporation problem at very high temperatures. The loss rates plotted in Fig. 1 are derived from data for evaporation into a vaculm except for the UC-ZrC* curve which represents the evaporation of $\mathrm{U}_{0.05} \mathrm{Zro}_{0.95} \mathrm{C}_{1.07}$ into hydrogen gas maintained at 1 atmosphere pressure. ${ }^{8}$ The evaporation rate of U0.05Zro.95 $C_{1.07}$ appears to be reduced from the vacuum evaporation rate by a factor of about eight.

These loss rate curves imply that even the most refraclory uranium-bearing materials will require some sori of containment to reduce material losses by evaporation 6 acceptable levels. A clear illustration of this point is seen by noting that the evaporation loss ralc of the least volatile fuel urm listed in Fig. 1, UC-ZiC* ${ }^{*}$ is more than a micron per second at $3500 \mathrm{~K}$ even when suppressed by a hydrozen atmosphere.

Evaporation from these luel forms also effects their chemical composition because of differences iit the evaporation rates of the constituent elements. The equilibrium com, osition of a frcely evaporating uranium carbides or oxides varies with temperature and is determined by the relative evaporation rates of the constituents. For cxample, the $\mathrm{O} / \mathrm{L}$ atom ratio at $2300 \mathrm{~K}$ for $\mathrm{UO}_{2}$ congruently cvaporating in a vacuum is 1.94.7 Most carbides are carbon delicient when congruently evaporating into a vacuum. Operating or processing environments may also alter the composition in relatively short times if there are chemical driving torces for reaction with one or more of the constituents.

The evaporation loss rate of cungsten is included in the plot in Fig. I because it is the least volatite of the refractory metals and it has been demonstra:ed as a compatible contuiner material for $\mathrm{UO}_{2}$ lo very high lemperalures. Tungsten has also been considered for a uranium carbide container material, but due to the fact that lungst in reacts with carbon-bearing materials to form $\mathrm{W}_{2} \mathrm{C}$ at a significant rate." the luels whth uranium carbides contained in lungien may be limited to short operating times and temperatures below about $3060 \mathrm{~K}$, the melting point of $\mathrm{W}_{2} \mathrm{C}$.

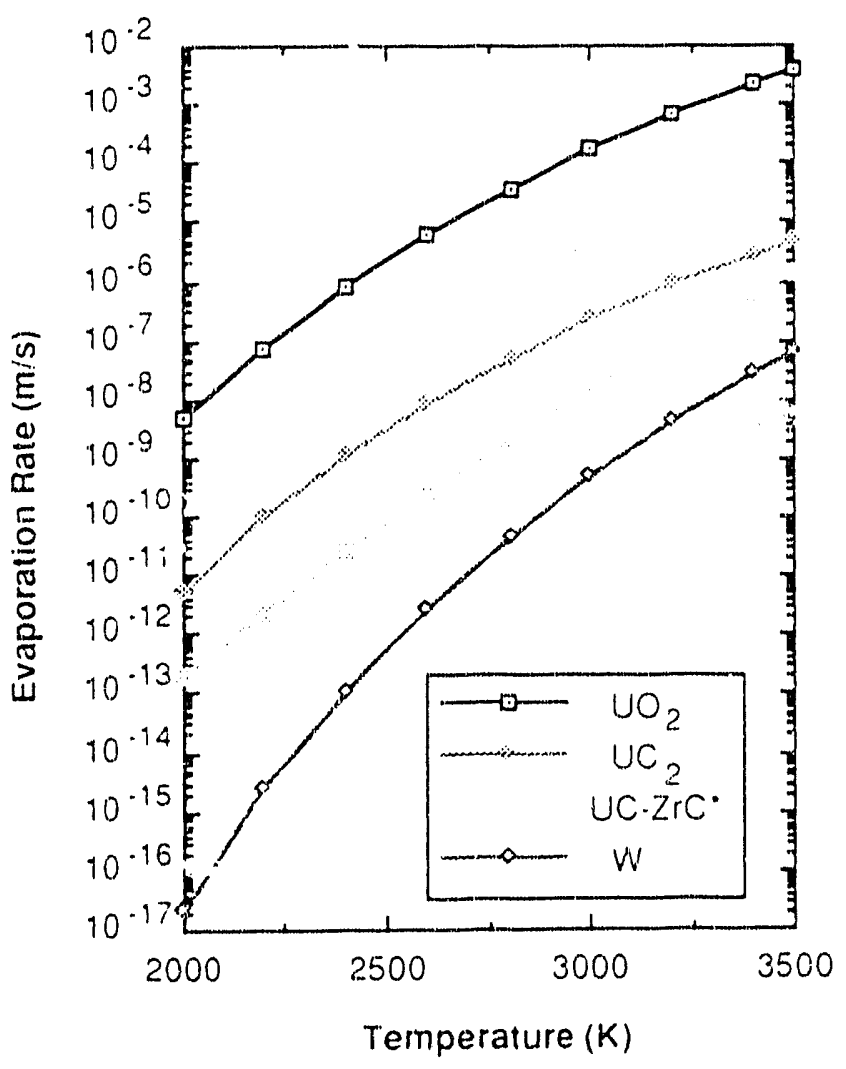

Fig. 1. Evaporation rates of several high tert.perature nuclear fucls and materials normalized to surfice regression ralcs.

Nelling represents the scound mosi important destgn

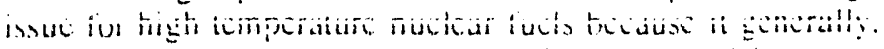
but not necessarily, fads to losis of fuel structural integray. Locillized. conbaned melling of the fucl component mght to 
acceptable for short limes in some cases. The moling temperatures of some high temperature fuel forms are listed in Table 1. As indicaled in Table 1, uranium carbicles mixed with refractory carbides, such as $\mathrm{ZrC}$, are the only fuel forms that can be expected to remain solid at the upper end of the temperature range under consideration. However, as indicated by the large difference between the melting temperatures of (U0.1 Zro.9) $\mathrm{C}_{0.96}$ and $\left(\mathrm{U}_{0.1} \mathrm{Zr}_{0.9}\right)_{0} \mathrm{C}_{0.98}$, the molting temperatures of this lype of material are very sensitive to the carbon contert. The melting temperature of the $W-6() \mathrm{v} / 0$ $\mathrm{UO}_{2}$ cermet is based on the melling temperature of $\mathrm{LO}_{2}$ even though the structural and geometric integrity of such a luet form might be maintained for short times 10 much higher temperatures.

Table 1. Melting and uranium concentration data for candidate high temperature nuclear fuels.

\begin{tabular}{|c|c|c|}
\hline Fuel Form & $\begin{array}{l}\text { Temperalure } \\
\text { (hi) }\end{array}$ & $\begin{array}{l}\text { U Densily at } 300 \mathrm{~K} \\
\left(10^{28} \text { atoms } / \mathrm{m}^{3}\right)\end{array}$ \\
\hline UC & $2805^{10}$ & 1.6 \\
\hline $\mathrm{UC}_{2}$ & 283510 & 0.9 \\
\hline$U C \cdot+0 \mathrm{ZrC}$ & $3050^{11}$ & 1.0 \\
\hline$\left(L_{0}\left(Z_{1} \mathrm{r}_{0.9}\right) \mathrm{C}_{0.96}\right.$ & $3550^{12}$ & 0.3 \\
\hline$\left(U_{0.1} \operatorname{Zr}(0.9) C_{0} 0.98\right.$ & $310\left(0^{12}\right.$ & 0.3 \\
\hline $\mathrm{W}-60 \mathrm{v} / \mathrm{O} \mathrm{UO}_{2}$ & $3075^{10}$ & 0.5 \\
\hline
\end{tabular}

Uranium densily is most important for fucls used in reactors whose neutron energy spectrum lends loward the high chergy or fast flux regime. This is driven by the lower fission cross-sections for fast neutrons as compared to those for slow or thermal neutrons. The $\left(U_{0,1} Z_{0}, y\right) C_{0}, 40$ luel form listed in Table 1 has sufficient uranium densily to be uscable in a thermal reactor, but its uranium density is loo low for use in most fast reactor designs.

The operating neutron spectrum of the reactor also has a msyor impact on the list of candidate materials that can be used in conjunction with the fucl material, such as cladding, cermet matrices or diluents. For example, significant quantitics of natural lungsten are unacceplable in a thermal reactor because of the high resonance and absorption cross-sections for slower neutrons found for most of the naturally occurring isotopes, while it is practical for use in a fast reactor because lew of those neutrons needed for last fissioning of uranum are lost to interactions with the tungsten. Enrichment of natural tungsten in the $184 \mathrm{~W}$ isotope is possible and has been considered for use in thermal reaciors. 13

High lemperature chemical stability of luef forms is important in itself, but "t is equally important for luc!s to not be chemically attacked by the matcitals found in the operating environment. For example, hydrogen is the propellant of choice for NTP, but hydiogen can reduce or remove oxygen from $\mathrm{UO}_{2}$ and cause the formation of liquid uramum in the lemperalure range under consideration. The umportance of the mainterance of optimum carbon content in the cartides has alleadt ineen indicated

Fabrication is aiways an mportan desgn consideraltion for high temperature luels, hut it becomes a major issuc for the complicated geometries required for extracing the high heis lluxes from niclear thermal rocted engunes. Nosi of the candidate high temperature fuel forms are difficuli to fabricate into the desired delicate shapes primarily due (1) their britte, refraciory nature.

Fission product release is expected to be very high for all uranium-bearing fuels operating beween 2000 and $3500 \mathrm{~K}$. $\mathrm{UO}_{2}$ fuel forms have been observed to relade noncondensibie fission products at their generation rates at $2000 \mathrm{k}$ and above, 14.15 while the fission gas release from carbide fuels is considerably less at temperatures as high as $2580 \mathrm{k}$. Io Fission product management is a major issue lor both NTP and high temperalure SNP applications.

Fission induced swelling behavior of lucls at high lemperature is important to the operation of all NTP and high lemperature SNP designs. Fuel swelling will generally lead to coolant passage closture in NTP reactor cores, while it will lead to mechanicai fistortion and loss of performance in thermionic SNP systems.

High temperature creep deformation in fuel forms must be mairlained al low levels in both NTP and SNP cores, so that overall core distortions are kept to a minimum. In general creep, outside of that produced by fuel swelling and thermal stresses, is most significant to ground-test conditions where the lorces of gravity can ate on the realior core. Creep lature of fuel claddings or coatings is generally unacceptable becaluse it leads in problems such as uncontrolled luet or lisston product release.

Thermal shock resistance of high lemperalure fuel forms is essential to both NTP and SNP cores because thermal transients and gradients will be an integral part of the normal operating environment for any design and the candidate luel forms lend to be brilde during reactor startup. The thermal shock resistance of a brutie solid material is proportuonat io its thermal conduclivity and fracture strength. while il is inverse!y proportional to its elastic modulus and thermal expansion cerllicient.

Because the high temperature luel forms are w he used in devies that will be launctice into space, 11 is important 10 consider their mass densily. For example, carbide batad lue? form: have mass denstices conslderably below those that include lungsten as a cladding of cermel matrix maleras.

\section{OXIDE FUEI. FORMS}

In sple of relatively modest melung temperature and uranum densily, $\mathrm{LO}_{2}$, has potenual for use in tuel lorms operaung to approximately $300(0) k$. The high volatulug of UO, requires that this tue form be conlaned inside some sor of sealed structure such as a claddeng or a conunuous metal matrix icermet). There is some evidence that $\mathrm{LO} \mathrm{O}_{2}$ can he successlully contalned in lungston rear the LO? mellin: emperature for shor umes. t.7. Molybdertum can be used as a contanment materal in the vicunity of zoloil $k$. Other refraciory mekals, such as noblum or tantalum. camnos be used for long-lem, high-lomperature conlatnment of $\mathrm{LO}=$ due 10 chemical incompatability. Times for successiul contamment are expected to be inversely proportonal to the cemperature as well as contarament material dependent

Duting fissioning at high lemperatures. contanted $\mathrm{UO}$ ? lusel bodies quickly hecome hollow and strongly bonded to the

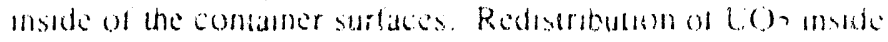

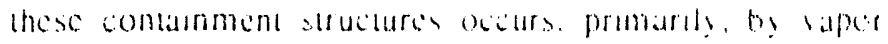

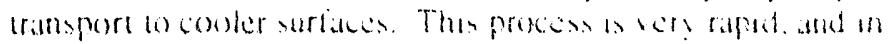

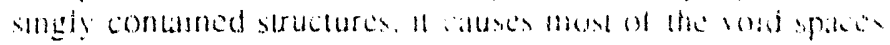


found in the virgin fuel to be collecind and lormed into a large cavity inside the fuel at locations furthest removed from the cooler regions.

The high vapor pressure of UO2 demands that its containment be very reliable for high temperature applications. This renuirement is difficult to achieve for long duration operation especially when the generated fission gases have to be contained or released in a controlled manner.

Under steady operating conditions, nencondensible, chemically inert fission products such as xenon or krypton are observed to be released at their generation rates throughout the entire temperature ranse alter a brief incubation period. ${ }^{14.15}$ Microstructural features, primarily interconnected grain boundary voids, developed in $\mathrm{UO}_{2}$ during fissioning at high temperatures allow free passage of the fission gases to the outside. ${ }^{17}$

Very litlle is known aboul the behavior of $\mathrm{UO}_{2}$ during irradiation at temperatures above $2000 \mathrm{~K}$. Data on the irradiation swelling of $\mathrm{UO}_{2}$ at the higher temperatures are sparse and somewhat questionable. However, ar algorithm has been published in a material property library called MATPRO ${ }^{18}$ that is claimed to be based on experimental data and able 10 predict the swelling of $\mathrm{UO}_{2} 102800 \mathrm{~K}$. The swelling predicted by this algorithm is ploted as a lunction of both temperature and burnup in Fig. 2. Swelling data in the 2000 to $2200 \mathrm{~K}$ regume 14.35 fill close is the plolled surface within the burnup values indicated in the phot. A mechanistic computer code called FASTGRASS. ${ }^{19}$ which calculates ${ }^{10} 0_{2}$ swelling and fission produrt release, appears to underpredict swe!ling in the 2000 to $2200 \mathrm{~K}$ iomperature range. Experimental data have not been found to compare with hisher semperature swalling predictions which indicate reduced swelling with increased temperature.

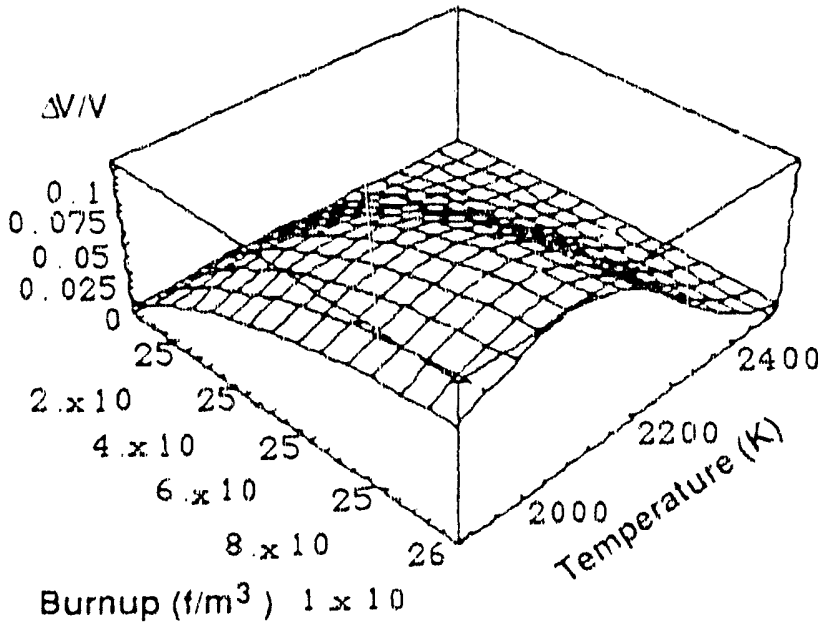

Fig. 2. $\mathrm{UO}_{2}$ irradiation swelling predicted by the MATPRO algoritum.

Irradiation swelling data on the tungsten-UOA cermets:-1) appear to follow the urends indicaled in Fig. 2 over the lemperature range 2000 10 $2300 \mathrm{~K}$ and burnups in the neighborhood of $10^{26} \mathrm{f} / \mathrm{m}^{3}$. However the otherved swelling is higher than predicted at the lower end of the emperature

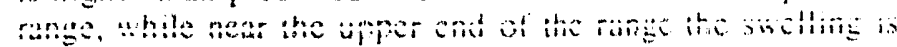
less thin predicted by MATPRO.
Management of the released fission gases is necessary for safe and reliable operation, and fission gas venting without significant fuel loss or unaceeplable redistribution within it reactor core is a major lectmological challenge to the utilization of $\mathrm{UO}_{2}$ for long durations at these very high temperatures. Fuel cladding vent systems have been used in TFE designs to allow the fission gases to be released from the containment to prevent unacceptably high cladding stresses without significant loss of $\mathrm{UO}_{2} .21 .22$

Because $\mathrm{UO}_{2}$ can be reduced in hydrogen al high temperatures, its chemical stability has been modified by the addition of more stable oxides such as $\mathrm{Gd}_{2} \mathrm{O}_{3}{ }^{7}$ and $\mathrm{ThO}_{2} .6$ The incorporation of these mixed oxides into a tungsten clad tungsten cermet matrix further improves their chemical stability in hydrogen.

Thermal expansion mismatch between $\mathrm{LO}_{2}$ and tungsten has been a concern especially for the application of the tungsten- $\mathrm{UO}_{2}$ cermets to NTP. However, considerable testing has indicated that the tungsten matrix is sufficiently robust io withstand tens of thermal cycles 10 temperatures near 2800 K.6.7 Good thermal shock resistance of the tungsten. $\mathrm{UO}_{2}$ (cermets was also demonstrated in these tests.

\section{CARBIDE FUEL FORMS}

As with $\mathrm{UO}_{2}$, the evaporaton rates from undiluted and uncontained uranium carbides are excessive above $2000 \mathrm{~K}$. Also, as indicated in Table 1 . their melting temperatures are not exceptional. Because $U_{2} C_{2}$ is typically used as a nuclear fuel along with carbon, the melting temperature lisied for UC, in Table 1 is actually the $U C_{2}+\mathrm{C}$ eutectic lemperature. However, as we have discussed, the evaporation of aranum carbides is effectively suppressed by dilution with less volatk refractory carbides. Simple containment of the carbides has not been very successful for long durations hor lack of a chemically compatible sontuiner maicrial.

The melung lemperature of UC caln be eflecusely increased by forming solid solutions with higher melting metal carbides, such as $\mathrm{ZrC}, \mathrm{NhC}, \mathrm{HrC}$, and $\mathrm{TaC}$. In the (U.Zr)C system, for example, solidus temperdiures in excess of $3570 \mathrm{~K}$ have been measured for compositions up in 10 mol\% UC. ${ }^{11}$ Increases in solidus temperature by adding NbC 10 (U, $\mathrm{Zr}) \mathrm{C}$ have been measured. "1 Even higher solidus cemperatures mas be possible in solutions of UC with HIC and $\mathrm{TaC}$.

The highest melting lemperature compusituons of the refractory melal carbides ( $\mathrm{ZrC}, \mathrm{NbC}, \mathrm{HCC}, \mathrm{TaC}$ ) are hypostokhiometric in carbon. For example. the hughest melling temperature in the Ta-C system. $+258 \mathrm{~K}$. has a $C T_{\text {a }}$ ratio of 0.89 .10 However buth higher and lower carbon contents cause precipilous decreises in the soldus temperatures due to eulectics on the order of $3(0) .8(0) K$ below the highest melling terraperature. Eutecuss with the metals are found in these systems at even lower lemperatures than those with carbon, but the drop in solidus temperature with addation of metal (loss of carbon) from the highest melung composuon is !ess steep. This limitation was recognized by fuel designers in the Roter/NER VA program. 12

Measurcment of the soludus at very ingh temperatures is

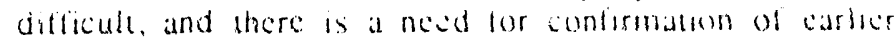

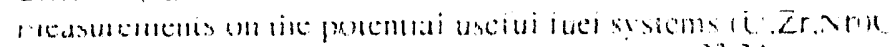
and L i ith Tak. Work in the area is underway 2.24 
It will be difficult to mainlain the optumal composition of the carbide fuels during high lemperature operation in either an NTP or SNP reactor because of the chemical imbalanees that will be imposed by the operaling crivironmert, including surrounding materials. For example, hydrogen will tend io react with all forms of uranium carbide to reduce their carbon contents and melting temperatures.

Similar to UC, (U, Zr)C fucls have exhibited large fission swelling rates at modest burnups. Ranken 16 has reported results on $(\mathrm{U}, \mathrm{Zr}) \mathrm{C}$ swelling, and these results are plotted in Fig. 3 along with results from UC. These results show that (a) the UC and $(\mathrm{U}, \mathrm{Zr}) \mathrm{C}$ data form one datil set, (b) swelling is strongly temperature dependent, occurring at very large rates $\left(>10 \% / 10^{26} \mathrm{f} / \mathrm{m}^{3}\right.$ ) at temperatures above about $1870 \mathrm{~K}$, and (c) swelling is negligible al fission diensities less than $1 \times 10^{25} \mathrm{f} / \mathrm{m}^{3}$ (equivalent $10-0.3 \%$ FIMA) for theoretically dense $\left(\mathrm{U}_{0.1} \mathrm{Zr}_{0.9}\right) \mathrm{C}$ fuel. These data were oblained all lission rates considerably below that expected in NTP reactors. However, if fission rate does not significantly affect the swelling rate of the carbides, swelling is not likely to be a problem for NTP applications, but it remains a concern with (U,Zr)C fuels for long term applicallions where the burnup and temperature requirements combine to place the fuel in a region where swelling is large.

A reduction in volumetric swelling $102.4 \%$ has been reported by Keller and Chubb 25 by the use of $20 \%$ porosity, combined with a 10 vols centerline hole and $0.51 \mathrm{~mm}$ tungsten cladeling with $\left(\mathrm{U}_{0.1} \mathrm{Zr}_{0.9}\right) \mathrm{C}$ irradiated in the temperature range $1870-2093 \mathrm{~K}$ io $1.9 \times 10^{26} 1 / \mathrm{m}^{3}$ compared with $17 \%$ for similar $\left(\mathrm{U}_{0.9} \mathrm{Zr}_{0.1}\right) \mathrm{C}$ clad with $0.51 \mathrm{~mm}$ tungsten-26 wt \% rhenium (W-26Re) and $40 \%$ for dense UC clad with $0.51 \mathrm{~mm} \mathrm{~W}-26 \mathrm{Re}$. In this temperalure range the tungsten cladding was enough stronger than the W-26Re cladding that the $\left(\mathrm{U}_{0.9} \mathrm{Zr}_{0.1}\right) \mathrm{C}$ fuel material filled the centerline hole first before causing externa! swelling. The fission gas retention in the $80 \%$ theoretical density $\left(\mathrm{U}_{0.1} \mathrm{Zr}_{0.9}\right) \mathrm{C}$ was $30 \%$ compared with $58 \%$ in dense UC.

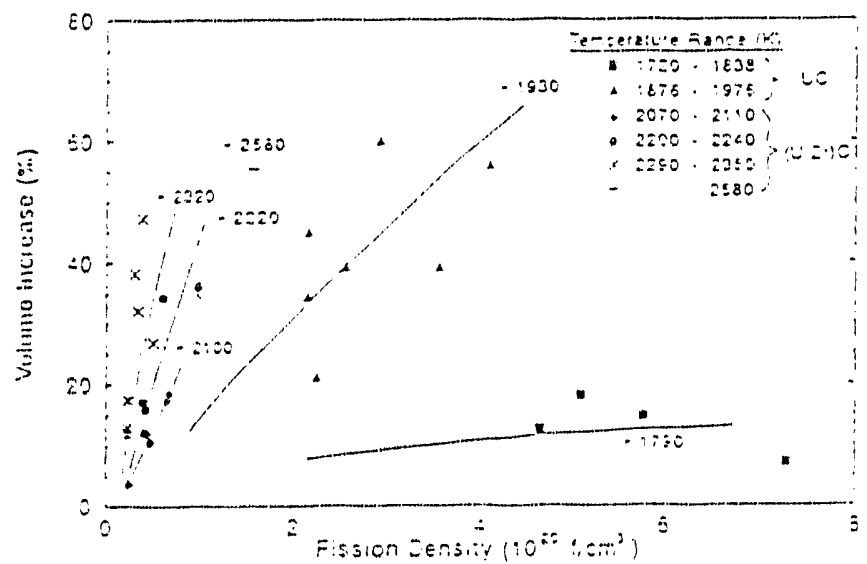

Fig. 3. Volumerric swelling of UC and (U.Zr)C als at function of fission density and irradiatuon temperature. (Reference 10$)$

Rasken ${ }^{16}$ reported fission gas releases in the range 15 . $65 \%$ for (U.Zr)C containing is and $30 \%$ \& $C$ with porosatles trom 310 20\%, and irradiated an temperalures trom 2070 60

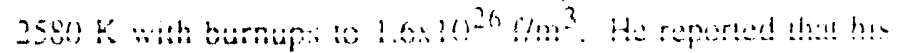

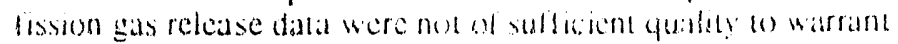

corrclation with temperature, porosity or burnup. Smith2t measured the release of $66 c_{i}$ of $\$ 5 \mathrm{Kr}$ from $\left(\mathrm{U}_{0.9} \mathrm{Zr}_{(0.1}\right) \mathrm{C}$ containing $24 \%$ as-fabricaled porosity and small holes in the fuel body to entance gas release and irradialed at a maximum temperalure of $2035<$ to a burnup of $3.0 \times 1()^{26} \mathrm{r} / \mathrm{m}^{3}\left(1.5^{\mathrm{c}} \mathrm{c}\right.$ FIMA) and $85 \%$ release of $85 \mathrm{Kr}$ from $\left(\mathrm{U}_{0.5} \mathrm{Zr}_{0.5}\right) \mathrm{C}$ containing $25 \%$ as-fabricated porosily and gas release holes and irradiated at a maximum temperature of $1995 \mathrm{~K} 10$ a burnup of $2.1 \times 10^{26} \mathrm{f} / \mathrm{m}^{3}(1.7 \%$ FIMA $)$.

Smith ${ }^{26}$ reported fractional retentions lor other fission products. Releases derived from reported retentions at the locations corresponding to the maximum irradiation temperatures and closest to regions of cracks in the tungsien cladding were greater for the fuel containing $50 \%$, UC $(1995 \mathrm{~K}$ maximum) than the fuel containing 9() UC $2035 \mathrm{~K}$ maximum). The values reported are ${ }^{90} \mathrm{Sr}(99$ and $86 \%)$. ${ }^{137} \mathrm{Cs}(95$ and $88 \%),{ }^{144} \mathrm{Ce}(93$ and $80 \%)$, and ${ }^{95} \mathrm{Zr}(19$ and $15 \%$ ). Kirk 27 reported fission product releases from luel: tested in the Nuclear Furnace 1 experiment. For the (U,Zr)C. graphite composite elements at the location of maximum fuel temperature $(2500 \mathrm{~K})$, the releases derived from reported retentions averaged $71 \%$ tor ${ }^{13 \hat{1}} \mathrm{l}, 64 \%$ tor ${ }^{89} \mathrm{Sr}, 36 \%$ for ${ }^{91} \mathrm{Y}$. and $30 \%$ ror ${ }^{140} \mathrm{Ba}$ relative $10{ }^{95} \mathrm{Zr}$. For the (U.Zr) C carbide eiements at the location of maximum fuel temperalure (24)() $\mathrm{K})$, releases relative $10{ }^{452 \mathrm{z}}$ were $15 \%$ lor both ${ }^{89} \mathrm{Sr}$ and ${ }^{91} \mathrm{Y}$ and $13 \%$ for ${ }^{140} \mathrm{Ba}$. These data indicate improved fission product retention for the earbide chements retallive to the composite carbide-graphite elements.

The fission product relcases derived from retention measurements of $\mathrm{Smith}^{26}$ and Kirk ${ }^{27}$ confirm expectations from studies on fission product retention in $\mathrm{UC}_{2}: 28$ namely, fission gases and iodine will be mostly released. strontium and cerium carbides have relatively high vapor pressures and will be released to a large extent from $U C$ and $(U, Z r) C$ fuels, Cs remains metallic, is rolatile and will be released from these fuels, and zirconitom forms a stable carbide with a relauscly low vapor pressure and will tend to be retained in the fuel 10 a greater extent than other lission producks.

Fission profuct containment in the uranum carbide based fual forms has traditionally been acheved by encapsulation or imbedding in chemically compatuble matrix materials such as graphte (pure carbon) and overcoatung whth contames materials, such as $\mathrm{ZrC}$ lor high temperature applicatuons. that can further inhibit lission product transport. These refractory carbides are also needed to protect the graphite matrices or coatings from altick by hydrogen in NTP applicalions.

Excessive mass losses from the cores of NTP reactors with uranium cartide based luels due 10 evaporation and reaction with hydrogen has been decermined to be a major concern. Beth materials and environment control the losses. For example, sbC coated graphle luel elements wath pyrolytic carbon coaled $\cup C_{\text {? }}$ were tound on have unace eptably high loss rates from operatung Rover/NERVA VTP test reacior cores due wo the hagh carbon diffuston rate through the NhC. coutung. However, the use of $\mathrm{ZCC}$ coalungs, whith have lower carbon diffusion rates than NAC, did not totally solve the mass loss problem due to cracking of the coatungs caused by irradiation cifects to the substrate in low temperature resumes of the core. Exessive coding cracking was seen on thuse cors

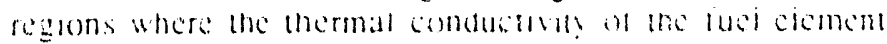
geraphate matrix was serousl: degrided be orradiatson damagle 
causing a significant increase in the thermal strains, even under stcady conditions. 12

The thermal shock resistance of candidate uranium carbide based fuel forms is of considerable importance to fuel element design. Sudies in the Rover/NERVA ${ }^{12}$ program indicoted that a graphite matrix composite containing 30 vol\% $\left(\mathrm{U}_{0.9} \mathrm{Zr}_{0.1}\right) \mathrm{C}$ possessed the best thermal shock resistance of the fuels tested. Increasing concentrations of $\left(U_{(0.9} \mathrm{Zr}_{0.1}\right) \mathrm{C}$ caused a decrease in the thenmal shock resistance. The graphite matrix provides those inherent properties previously listed that produce good thermal shock resistance. Monolithic carbide structures have much poorer thermal shock resistance than the composites because they have signilicanlly lower thermal conductivities and higher elastic moduli than the matrix graphite. This comparative behavior was demonstrated in an NTP test reactor even though the thermal conductivity of the matrix graphite was seriously degraded in the low temperature region of the core, probably by fission fragment damage, which caused matrix surface cracks 10 develop. ${ }^{12}$

\section{CONCLUSIONS}

It has been concluded that evaporation is the most important fuel design issue for applications in the temperature range $2000103500 \mathrm{~K}$, and melting temperature has been concluded to the second most important luel design issue. Other design issues have been defined that tend to be more closely related to the particular application and fuel material. However, there does not appear to be either sufficient experience or data bases to be assured that all of the critical design issues have been defined.

Fuel forms based on $\mathrm{UO}_{2}$ and uranium carbide appear to be promising candidates for application in this temperature range, but data are sparse above $2000 \mathrm{~K}$. Relevant, referencabie data on the nuclear performance of UO a appears to excend to only about $2400 \mathrm{~K}$, while similar data on uranium carbide based fuels extends only 10 about $2600 \mathrm{~K}$. Experimental data direchly relevant to reactor design and operation are virtually nonexistent near the upper end of the temperature range of interest. In short, the future development of advanced high temperature nuclear power or propulsion systems depends very heavily on the development of a full understanding of the luel behavior in this severe enviromment.

\section{ACKNOWLEDGEMENT}

This work wals supported by the U.S. Department of Energy, Assistant Secretary for Nuclcar Energy, under DOE Idaho Field Office Contract DE-AC(17-761D(1570).

\section{REFERENCES}

1. Culver, D. W'. W. B. Dahl, and M. C. Mcllwain, "A L Mque Nuclear Thermal Rocket Engine Using a Particle Bed Reactor," in Procectings of lha Ninth Svoosium on Space Nuclair Power Sustems, M. S. El. Gerik and M. D. Hoover, eds., American Institute of Physics, Part 11, New Yort (1992) pp. 714+720.
2. Jacox, M. G., R. G. Bennell, L. B. Lurdberg, B. G. Miller, and R. L. Drexler, "Small Ex-Core Heal Pipe Thermionic Reactor Concept (SEHPTR)," in Procedings of the 26uh Intersociow Energy Conversion Enginecring Conference, $V_{0} \mid, 1$, American Nuclear Sociely, La Grange Park, IL (1991) pp. 420-445.

3. Zubrin, R. M., T. K. Sulmeisters, M. G. Jacox, and K Watis, "The Integraled Power and Propulsion Stage: A Mission Driven Solution Utilizing Thermionic Technolgy," in Proceedings of the Ninch Sunosium on Space Nuclear Power Sustemss, M. S. El-Genk and M. D. Hoover, eds., American Instilute of Physics, Part II, New York (1992) pp. 1259-1267.

4. Koenig, D. R., "Experience Gained from the Space Nuclear Rockel Program (Rover), * Los Alamos National Laboratory Report No. LA.10062-H (May 1986).

5. Rom, F. E., "Review of Nuclear Rockel Research at NASA's Lewis Research Center trom 1953 thru 1973." presented at the DIAA/NASA/OA Conterence on Advanced SEl Technologies Paner No AlAA 91.350), Sept. $4-6,1991$, Cleveland, $\mathrm{OH}$.

6. General Electric, Nuclear Matcrials \& Propulsion Operation, "710 High Temperalure Gas Reactor Program Summary Report, Vol. II!-Fuel Element Develpment," General Electric Co. Report No. GEMP $600(1968)$

7. Argonne National Laboratory, "Nuclear Rocket Program Terminal Repon," Argonne National Laboratory Report No. ANL-7236 (June 1966).

8. Siorms. E. K., D. Hanson, W. Kirk, and P. Goldman. "Elfect of Fuel Geometry on the Lifetime-Temperature Performance of Advanced Nuclear Propulsion Reactors," presented at the AIAA/NASA/O 1 Conterence on Advanced SEl Technologies Paner No. ALAA 91-3454, Sept. 4.6, 1991, Cleveland, OH.

9. Lundbery, L. B., "Silicon Carbide-Tungsten Heat Pipes for High Temperalure Service." ISEC Product Research and Development, 19 (1980) pp 241-244.

16. Massalski, T. B. Binary Alloy Phase Diagrams Vol 1. American Society for Metals. Metuls Park, OH (1986).

11. I. P. Tosdale, "Refraciory Melal-Carbide Systems, M. $S$. Thesis, Ames Laboratory, Iowa State Universily. 1967.

12. Lyor, L. L., "Performance of (U.Zr)C.Graphite (Comfosite) and of (U.Zr)C (Carbide) Fuel Elements in the Nuclear Furnace I Tesi REacior." Los Alamos National Laboratory Report No. LA.5398-MS. Sept. (1973). 
13. Rom, F. E., "Review of Nuclear Rocket Research at NASA's Lewis Research Center from 1953 thru 1973," presented at the AIAA/NASA/OAI Conference on Advanced SEI Technologies, Paper No. ALAA 91-3500, Sept. 4-6, 1991, Cleveland, OH.

14. Zirnmerman, H., "Investigations on Swelling and Fission Gas Behavior in Uranium Dioxide," J. Nucl. Mal., Vol. 75 (1978) pp 154.161.

15. Keller, D. L., Progress on Develonment of Fiels Technology for Advanced Reactors During July 1970 through June, 1271, BMI-1918. Battelle Columbus Laboratories, Columbus, OH (July 1971).

16. Ranken, W. A., "Swelling of UC-ZrC Fuels Irradiated at High Temperature," Space Nuclear Power Sustems 1988, Orbit Book Co., Mialaba, FL (1989) pp. 231 242.

17. Chubb, W., V. W. Storhok and D. L. Keller, "Observations Relating to the Mechanisms of Swelling and Gas Release in Uranium Dioxide al High Temperatures," J. Nucl. Mal., Vol. 44 (1972) pp 136 152.

18. "SCDAP/RELAP5/MOD2 Code Manual, Volume 4: MATPRO - A Library of Materials Properties for Light-Water-Reactot Accident Analy'sis," NUREG/CR5273, U.S.Nuclear Regulalory Commision, Washington, DC, (Feb. 1990) p. 2.14-2.

19. Rest, J, and S. A. Zwadzki, "FASTGRASS: A Mechanistic Model for the Prediction of Xe, I, Cs, Te, $\mathrm{Ba}$ and Sr Relcase from Nuclear Fuel Under Normal and Severe Accident Conditions," Argonne National Laboratory Report (To he published).

20. "High Temperature Materials Program Progriss Report," GEMP-53B, General Electric Co. (Nov. 1965).

21. Gonlar, A. S., M. V. Nelidov, Y'u. V. Nikolaev, Y'u. N. Podogov, L. N. Solovyov, V. N. Somikov, and L. N. Shulepov, "Problems of the Thermionic Fucl Element Development," presented at the Anniversary Speciali : Sonference on Nucleit Power Engincering in Space, May 15-19, 1990, Obninsk, Institute of Physics and Power Engineering.

22. Gontar, A. S., R. Ya. Kucherov, M. V. Nelidov, Yu. V. Nikolaev, V. N. Solnikov, and L. N. Shulepov, "Some Questions of Uranium Dioxide Mass Transfer Influence on High-Temperalure Fuel Element Behaviour," in Proceedings of the 24th lillersociely Energy Conversion Engineering Conference : $/ 01$, Aus. 6-11, 1989, Washington, DC, IEEE, NY (1989) pp 2803-2808.

23. Carmack, W. J., R. R. Hobbins, and P. A. Lessing, "Mixed Carbide High Temperalure Fucls," AlAA91. 3453. A.AA/NASA/OAl Conlerenci on Advaneed SEI Technologies, Cleveland, September A-6, 1991.
24. Santandrea,R. P., A. H. Bremser, and H. H. Meoller, "Determination of High Temperature Phase Relationships and Ternary (U,Zr,Nb) Carbides," Ninth Symposium Space Nuclear Power Systems, Albuquerque, January 12-16, 1992.

25. D. 1.. Keller and W. Chubb, "Annual Report, Progress on High-Temperature Fuels Technology During August, 1968 Through July, 1969," Battelle Memorial Institutc, Columbus Luboratories, BMI-1870 (August 1969).

26. J. R. Smith, "Examination of UC-ZrC After Long Term Irradiation at Themionic Temperature," NASA Lewis Research Center, NASA-CR-120995 (December 1972).

27. W. L. Kirk, "Nuclear Fumace-1 Test Reporl," Los Alamos National Laboratory, LA-5189-MS (March 1973).

28. Myers, B. F., N. L. Baldwin, and W. E. Bell, "Fission Gas Release from Fuel Particles and Fuel Rods," Nucl. Techn., Vol. 35 (Sept. 1977) pp. 501.508

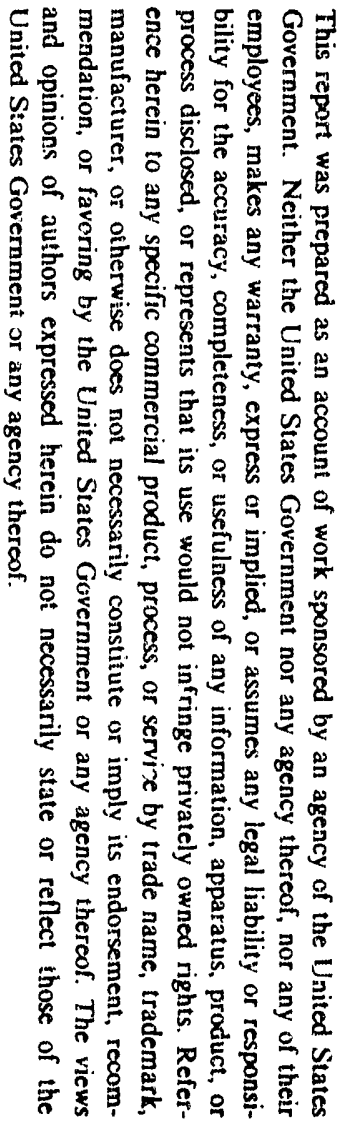



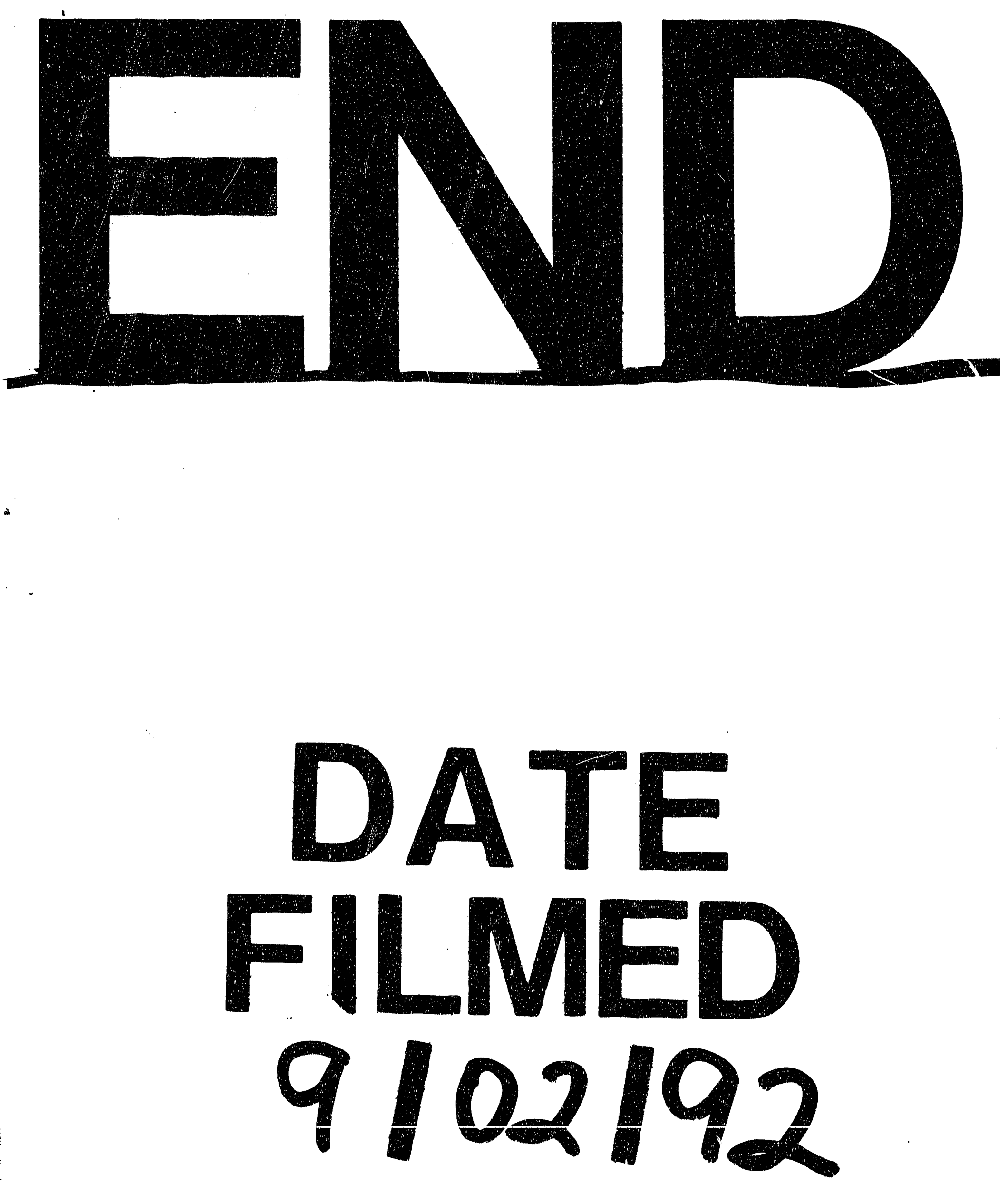
